\title{
ISU DASAR NEGARA INDONESIA MENJELANG PEMILU 1955: Studi Kasus Pidato Politik Soekarno Di Amuntai 27 Januari 1953*
}

\author{
Muhammad Iqbal**
}

\begin{abstract}
"Islamic State versus National State" was a heated political issue throughout the 1950s that created bighly tense and dividing debates among Indonesia's political communities. President Soekarno, a leading proponent of National State, raised this issue for the first time in his speech in Amuntai on January 27 ${ }^{\text {th }}, 1953$. The present paper contends that this speech was crucial for the political discourse contestations that followed between the religiously-neutral Nasionalist camp and the Islamic camp. The former argued against the latter's idea of building an Islamic state in Indonesia and proposed instead, a secular state that guarantees the right of its citizens to observe their religious teachings. The value of Soekarno's speech could be seen from reactions it generated from the supporters of Islamic State who called it a smear campaign and a doctrine dangerous to their struggle to erect an Islamic state in Indonesia.
\end{abstract}

Kata kunci: negara Islam, nasionalis netral agama, pidato politik.

\section{Pendahuluan}

Isu negara Islam dengan berbagai model dan variannya bukanlah sebuah isu yang telah mati. Hingga tahun 2011, media di Indonesia masih memberitakan kehadiran Negara Islam Indonesia dan berbagai kelompok

*Penulis mengucapkan terima kasih banyak atas diskusi, masukan dan kritikan dari: Saefur Rochmat, Mujiburahman, Ahmad Muhajir, Noorhaidi Hasan, Ben Anderson, Ben Abel, Bill Liddle, Bob Elson, Gerry van Klinklen, Greg Fealy, Merle Ricklefs, Bernhard Dahm, Anna Tsing, Andree Feillard, Henri Chambert-Loir, dan Martin van Bruinessen, terhadap draf awal hasil penelitian ini. Namun, seluruh isi tulisan ini merupakan tanggungjawab penulis.

${ }^{* *}$ Staf Pengajar pada Fakultas Hukum UNISKA Banjarmasin dan STAI Al-Falah Banjarbaru. Asisten Peneliti Prof. Benedict O’Gorman R. Anderson (Aaron L. Binenkorb Professor Emiritus of International Studies in Cornell University, Ithaca, New York, United State of America) untuk kawasan Indonesia. 
Muslim yang beraspirasi menegakkan Negara Islam atau sekurangnya memberlakukan Syariat Islam dalam kehidupan publik dan kenegaraan. Sesungguhnya hal ini adalah persoalan lama, yang dapat ditarik akarnya hingga ke masa awal berdirinya Republik Indonesia. Artikel ini akan mendiskusikan perdebatan panas dan membelah masyarakat politik Indonesia di tahun 1950an antara kelompok pendukung Negara Islam dan Negara Nasional. Berbeda dari banyak tulisan mengenai topik ini, penulis mengangkat peristiwa Pidato Sukarno di Amuntai 1953 sebagai momen sangat penting di awal kontroversi panjang tentang bentuk negara Indonesia. Penulis menegaskan bahwa pidato tersebut mengundang reaksi hebat dari para pendukung ide Negara Islam yang dimotori partai-partai Islam. Pihak yang terakhir ini menganggap bahwa pidato Amuntai-nya Sukarno, seorang pendukung konsep negara netral agama yang juga individu kharismatik serta tokoh solidarity maker, sebagai kampanye negatif dan menjadi sebuah doktrin berbahaya bagi cita-cita membangun Negara Islam di Indonesia.

Artikel ini bermaksud berkontribusi pada penulisan sejarah pertarungan wacana politik di Indonesia, khususnya pada isu Negara Islam. Penulis akan mengawali analisis dengan diskusi pengantar tentang wacana Negara Islam dan respon-respon dari berbagai kelompok Muslim di Indonesia. Selanjutnya, dengan pendekatan sejarah, penulis merekonstruksi peristiwa pidato Sukarno di Amuntai 1953. Di dua bagian terakhir sebelum simpulan, reaksi terhadap pidato itu dan respon balik Sukarno akan penulis uraikan.

\section{Isu Negara Islam dan Respon-respon dari beberapa kelompok Muslim: diskusi pengantar}

Bangsa Indonesia melihat kedudukan Islam dalam masyarakatnya sebagai masalah yang belum terpecahkan. Hal ini tercermin antara lain dalam perdebatan-perdebatan Badan Penyelidik Usaha-usaha Persiapan Kemerdekaan Indonesia (BPUPKI) pada 1945, polemik-polemik dalam permulaan tahun 1950-an yang dilanjutkan dengan perdebatan yang lebih panas pada sidangsidang Konstituante sejak 1955 hingga 1959. Para pendukung ide masuknya Islam dalam kehidupan kenegaraan di Indonesia berpendapat bahwa ciri dasar dari agama Islam tidak memungkinkan negara menjadi bersifat teokrasi, karena Islam tidak mengakui sistem kependetaan. Negara Islam, kata mereka, adalah sebuah negara yang melaksanakan ajaran Islam di tengah masyarakat untuk kepentingan dan keuntungan masyarakat secara keseluruhan. Tetapi 
pendukung-pendukung ide ini mempunyai perbedaan tafsiran ihwal cara melaksanakan konsep ideologinya. Perlukah seorang mempunyai kekuasaan di tangannya lebih dahulu untuk melaksanakan ajaran-ajaran dasar itu, ataukah harus dilaksanakan usaha menyebarkan ajaran-ajaran Islam terlebih dahulu di tengah masyarakat? Kedua hal tersebut perlu dilaksanakan dalam waktu yang sama. Akan tetapi masyarakat Islam berbeda sikap dalam masalah ini, mulai dari paksaan di satu pihak sampai kepada cara-cara yang demokratis. Partaipartai Islam di Indonesia pada umumnya memilih jalan dan pandangan yang damai dan demokratis itu. Beberapa pihak dari masyarakat memang kurang toleran dan menuntut cara-cara yang lebih keras, namun mereka ini termasuk golongan minoritas dan biasanya juga mengikuti kepemimpinan yang lebih didorong oleh ketidaksabaran melihat segala macam perlakuan yang diderita kalangan Islam sendiri.

Masalah lain yang dihadapi oleh masyarakat Islam di Indonesia adalah bahwa mereka lebih banyak terlibat dalam pertikaian yang bersifat teoritis dan ideologis, baik dalam berhadapan dengan pihak Nasionalis Netral Agama ataupun di antara mereka sendiri, dan anehnya, tanpa banyak sangkut pautnya dengan dasar-dasar pokok dari Islam itu sendiri. Akibatnya mereka kurang memperhatikan masalah-masalah yang perlu segera diselesaikan oleh masyarakat Indonesia secara keseluruhan. Perbedaan pandangan dalam kalangan masyarakat Islam di Indonesia itu terlukis secara nyata pada hasil pemilihan umum (pemilu) pertama pada 1955. Pemilu itu memunculkan "Empat Partai Besar", yaitu Partai Nasional Indonesia (PNI) dengan jumlah suara 8,5 juta (22,3\%), Masjumi dengan 8 juta suara (20,9\%), Nahdlatul Ulama (NU) dengan 7 juta suara (18,4\%), dan Partai Komunis Indonesia (PKI) dengan 6,1 juta suara (16,4\%). Keempat partai ini berturut-turut memeroleh 57, 57, 45, dan 39 kursi di Parlemen yang terdiri dari 257 orang anggota. Di antara keempat partai besar itu, Masjumi dan NU merupakan partai Islam. Di samping itu, ada 4 partai kecil berbasis Islam yang juga mendapat kursi di parlemen, yakni Partai Syarikat Islam Indonesia, Perti, Partai Persatuan Tharikat Islam, dan Angkatan Kesatuan Ummat Islam dengan masing-masing 1.091 .160 suara $(2,9 \%, 8$ kursi), 483.014 suara (1,3\%, 4 kursi), 85.131 suara $\left(0,2 \%, 1\right.$ kursi), dan 81.454 suara $(0,2 \%, 1$ kursi $) .{ }^{1}$

${ }^{1}$ Tentang Pemilu 1955 di Indonesia, lihat Herbert Feith, Pemiliban Umum 1955 di Indonesia, a.b.: Nugroho Katjasungkana dkk., (Jakarta: KPG, 1999); Alfian, Hasil Pemilihan Umum untuk. Dewan Perwakilan Rakyat [DPR] (Jakarta: Leknas LIPI, 1971); Alfitra Salamm, 
Melihat fenomena beragamnya pendapat dan adanya perbedaan di antara partai-partai Islam dan di dalam lingkungan masyarakat Islam sendiri, mudahlah dipahami betapa hebatnya tantangan terhadap Islam di Indonesia. Apalagi jika diingat bahwa hubungan atau persoalan pribadi selalu masuk ke dalam kehidupan sosial-politik, dan sering membawa akibat yang lebih rawan dibandingkan dengan sebab-sebab perbedaan ideologi. Dukungan sebagian kalangan Islam terhadap rezim Soekarno, yang kebijaksanaannya waktu itu lebih memperkuat pihak Komunis dan melemahkan kedudukan Islam sendiri, merupakan pertanda jelas bahwa ideologi dan program bukanlah faktor utama untuk memahami kedudukan dan perkembangan golongan apapun di Indonesia, karena hubungan pribadi dan hubungan politik dalam konteks sejarah perlu juga diperhatikan. ${ }^{2}$ Hubungan politik antara kelompok Islam dan kelompok Nasionalis Netral Agama pada sebagian besar babakan sejarahnya, merupakan cerita antagonisme dan penuh kecurigaan satu sama lain. Hubungan yang tidak harmonis ini terutama, tetapi tidak seluruhnya, disebabkan oleh perbedaan pandangan pada pendiri republik ini yang sebagian besarnya Muslim, ihwal Negara Indonesia merdeka yang dicita-citakan. Salah satu butir terpenting dalam perbedaan pendapat di atas adalah: apakah Indonesia bercorak "Islam atau "Nasionalis?" Kelompok Islam berpendapat bahwa bangunan kenegaraan Indonesia yang pertama mengharuskan agar Islam, karena sifatnya dan kenyataan, bahwa agama itu dianut oleh sebagian besar penduduk, diakui dan diterima sebagai dasar ideologi negara. Kelompok Nasionalis Netral Agama atas pertimbangan bahwa Indonesia adalah negara yang secara sosial-keagamaan bersifat majemuk, maka demi kesatuan dan persatuan nasional harus didasarkan atas Pancasila, sebuah ideologi yang sudah dimufakati. Kenyataannya diskursus ideologis tersebut memancing munculnya konflik, hal itu tidak disebabkan oleh tingkat kesalehan keagamaan yang berbeda di kalangan umat Islam, sebuah pandangan yang melandasi konsepkonsep, seperti pengelompokan antara varian santri-abangan dan varian Islamsekular (atau netral-agama) yang terkenal itu. Konflik itu terutama disebabkan oleh ketidakmampuan elite politik nasional dalam mendamaikan perbedaanperbedaan pandangannya, seakan-akan Islam dan Nasionalisme merupakan dua entitas yang saling bertolak belakang.

\footnotetext{
"Pemilihan Umum dalam Perspektif Sejarah: Pengalaman 1955", dalam Syamsuddin Haris; dkk, Menggugat Pemilihan Umum Orde Baru (Jakarta: USAID \& Obor, 1998), h. 18-48.

${ }^{2}$ Lihat Deliar Noer, Partai Islam di Pentas Nasional: Kisah dan Analisis Politik Indonesia 1945-65, edisi kedua (Bandung: Mizan, 2000).
} 
Muktamar NU di Banjarmasin pada 9 Juni 1936, dalam hal ini telah membuat keputusan yang sangat unik sebagai jawaban atas masalah tersebut. Keputusan inilah yang nantinya akan melandasi sikap NU terhadap ideologi, politik, dan pemerintahan di Indonesia. Muktamar ini berhasil merumuskan jawaban terhadap pertanyaan atas status tanah Hindia Belanda, yang sedang diperintah dan dibela dari serangan luar bahwa hal itu wajib dilakukan menurut hukum agama (figh). Jawaban dikutip dari salah satu genre 'kitab kuning' yang berjudul Bughyatul Mustarsyidin karya Syaikh Hassan Al-Hadhrami, alasannya adalah negeri ini pernah mengenal kerajaan-kerajaan Islam, penduduknya sebagian masih menganut dan melaksanakan ajaran Islam, dan Islam sendiri tidak sedang dalam keadaan diganggu atau diusik. Duduk persoalannya, jelas sekali: selama kaum Muslimin dapat menyelenggarakan kehidupan beragama mereka secara penuh, maka konteks pemerintahannya tidak lagi menjadi pusat pemikiran. Pikiran seperti ini pula yang melandasi pandangan dasar kaum ablus sunnah waljama'ah, seperti penerimaan mereka atas kekhalifahan (caliphate) Usmaniyah di Turki atas seluruh dunia Islam, padahal mereka bukan dari suku Quraisy (menurut pandangan klasik paham Sunni, kepemimpinan negara atau imamah, termasuk yang berbentuk kekhalifahan, haruslah berada di tangan orang Quraisy, karena adanya ketentuan dari Nabi Muhammad sallallabu 'alaibi wassallam tentang hal itu), dengan ungkapan lain, pemerintahan ditilik dan dinilai dari fungsionalisasinya, bukan dari norma formal dari eksistensinya, negara Islam atau bukan. ${ }^{3}$

Konsep yang seperti itu dalam mendudukkan pemerintahan pada 'posisi netral' adalah inti dari pandangan mazhab Syafi'i ihwal 'tiga jenis negara': dar Islam, dar harb, dan dar sulh (negara Islam, negara perang, dan negara damai). Menurut paham ini, negara Islam harus dipertahankan dari serangan luar, karena ia merupakan perwujudan normatif dan fungsional dari cita-cita kenegaraan dalam Islam, dengan ciri utama berlakunya syariah Islam sebagai undang-undang negara. Negara perang atau negara anti-Islam, harus diperangi, karena berbahaya bagi kelangsungan hidup negara Islam, dan dengan demikian akan mengakibatkan dihilangkannya pemberlakuan syari'ab Islam dari undangundang negara. Negara damai harus dipertahankan, karena syariab (dalam bentuk hukum agama/fiqh atau etika masyarakat) masih dilaksanakan oleh

${ }^{3}$ Abdurrahman Wahid, "Kata Pengantar", dalam Einar Martahan Sitompul, NU dan Pancasila: Sejarah dan Peranan NU dalam Perjuangan Umat Islam di Indonesia dalam Rangka Penerimaan Pancasila sebagai Satu-satunya Asas (Jakarta: Sinar Harapan, 1996), h. 9-10. 
kaum muslimin di dalamnya, walaupun tidak melalui legislasi dalam bentuk undang-undang negara. ${ }^{4}$ Tahapan-tahapan dari keputusan NU atas netralitas agama dalam sistem ketatanegaraan Indonesia adalah sebagai berikut:

1. NU dalam muktamarnya yang ke-11 pada 9 Juni 1936 di Banjarmasin, memutuskan bahwa tanah air dan bangsa Indonesia wajib dipertahankan dari serangan luar, tanpa melihat sistem kekuasaan yang memerintahnya.

2. NU pada 1945 turut menerima dan merumuskan Pancasila dan UndangUndang Dasar 1945 (melalui kehadiran KH. A. Wahid Hasjim, KH. Masjkur, dan KH. Zainul Arifin). Keterlibatan mereka dalam pelbagai kegiatan nasional untuk menyongsong lahirnya kemerdekaan, berujung pada 'Resolusi Jihad' pada Oktober 1945, yang mewajibkan umat Islam untuk memperjuangkan kemerdekaan dan membela tanah air sebagai perjuangan di jalan Allah (jihad fi sabillillah). Sikap itu berarti dalam pandangan NU, yaitu menerima Indonesia tidak hanya sebagai tanah air (nusa) dan bangsa belaka, melainkan juga sebagai negara.

3. NU menempatkan Presiden Republik Indonesia sebagai 'waliyyul amri dharuri bissyaukah' (pemegang kekuasaan temporer atas pemerintahan, dengan kekuasaan efektif).

4. NU menerima pemerintahan Indonesia pasca kemerdekaan dari sudut pandangan keagamaan Islam, setelah penerimaan atas nusa-bangsa dilakukan di Banjarmasin dan penerimaan atas negara beserta ideologinya di Jakarta pada 17-18 Agustus $1945 .^{5}$

Diskursus ideologis ini pulalah yang menjadi persoalan genting dalam masyarakat Kota Amuntai sejak awal 1950-an. Penduduk Amuntai ditinjau dari sudut pemikiran keagamaan, termasuk penganut Islam "tradisionalis" sekaligus menjadi pengikut NU. Fenomena ini semakin menarik karena hanya beberapa kilometer saja dari Amuntai terdapat Kota Alabio, dimana sebagian besar penduduknya menjadi pengikut Muhammadiyah yang taat, mengingat zaman penjajahan sudah berdiri Persjarikatan Muhammadiyah di kota itu. ${ }^{6}$ Bagi umat Muslim di Hindia Belanda (umumnya) dan masyarakat Amuntai (khususnya) sejak zaman kolonial, berlaku anggapan bahwa Nusantara ketika masih dijajah hingga menjadi negara merdeka sejak 17 Agustus 1945 adalah "negerinya umat

4Abdurrahman Wahid, "Kata Pengantar", dalam Einar Martahan Sitompul, h. 10.

${ }^{5}$ Abdurrahman Wahid, "Kata Pengantar", dalam Einar Martahan Sitompul, h. 11.

${ }^{6}$ Achmad Fedyani Saifuddin, Konflik dan Integrasi Perbedaan Faham dalam Agama Islam (Jakarta: Rajawali, 1986), hlm. 53; lihat juga Alfani Daud, Islam dan Masyarakat Banjar Diskripsi dan Analisa Kebudayaan Banjar (Jakarta: Rajawali, 1997). 
Islam", yang secara singkat disebut "Negara Islam". Para politisi yang mendirikan dan memimpin negara ini telah merumuskan bahwa Negara Kesatuan Republik Indonesia (NKRI) ini adalah sebuah negara nasional yang berdasarkan Pancasila. Pada tahap-tahap awal kemerdekaan masalah ideologis tidaklah terlalu dipersoalkan, karena kita lebih banyak berkonsentrasi pada pembelaan negara dan melakukan perlawanan terhadap Belanda. ${ }^{7}$

"Pidato Politik Soekarno di Amuntai 27 Januari 1953" ini terjadi ketika sedang maraknya tuntutan untuk mewujudkan cita-cita negara Islam. ${ }^{8}$ Presiden Soekarno sebagai seorang penganut cita-cita nasionalis dan kesatuan, berpendirian sebaliknya. Hal ini sudah dapat terlihat sejak apa yang dilakukannya dalam pergerakan nasional dan lebih tampak lagi dalam perdebatan-perdebatan BPUPKI pada 1945 dimana setiap orang mengetahui bahwa Soekarno berada pada kubu yang berhadapan dengan kubu Islam, yakni kubu Nasionalis Netral Agama. Interpretasi pada tahun-tahun pertama kemerdekaan, karena tingginya semangat perjuangan, persoalan ini menjadi meredam untuk sementara waktu dan perhatian rakyat lebih tertuju ke arah perjuangan mengusir penjajah, selanjutnya pasca Indonesia berhasil melakukan pemulihan kedaulatannya, isu ini secara serta merta merebak kembali ke permukaan. ${ }^{9}$ Bung Karno sejak awal 1950-an mulai berbicara tentang ideologi Pancasila dan paham kebangsaan, terutama sekali sejak ia menerima gelar Doctor Honoris Causa dari Universitas Gajah Mada pada 19 September 1951 sebagai penghargaan atas jasanya sebagai "Pencipta Pancasila". Bung Karno sangat menekankan sekali ihwal kedudukan Pancasila sebagai dasar negara. Pidatopidato ini dinilai sebagai polemik terhadap pendapat-pendapat yang memperjuangkan cita-cita "Negara Islam", lebih-lebih pasca S.M. Kartosuwirjo pada 7 Agustus 1949 di Desa Cisayong (Jawa Barat) memproklamirkan berdirinya Negara Islam Indonesia (NII).

Ibnu Hajar, seorang mantan pejuang di Kalimantan Selatan, dalam kondisi yang demikian, selain karena masalah-masalah ketidakpuasan berkenaan dengan jabatan kemiliterannya, mengadakan "perlawanan" di Kalimantan Selatan dengan membentuk Kesatuan Rakyat Indonesia yang Tertindas (KRIyT), yang merupakan reaksi terhadap besarnya campur tangan

${ }^{7}$ Abdurrahman, "Peristiwa Amuntai 1953 dan Pengaruhnya Terhadap Perkembangan Politik di Indonesia", Banjarmasin: makalah diskusi redaksi Banjarmasin Post pada Sabtu, 19 September 1998, h. 2.

${ }^{8}$ Lihat Muhammad Iqbal, "Peristiwa Amuntai 1953”, Media Kalimantan, 3 Maret 2011.

9Jurnal Republik, edisi Selasa, 8 Januari 2008. 
pemerintah pusat, terutama sekali terhadap perwira-perwira yang berasal dari Jawa. Pemerintah pusat sangat mengkhawatirkan sekali terjadinya penyusupan gerakan Darul Islam (DI) dari Kartosuwirjo di Kalimantan Selatan, mengingat pengaruh gerakan ini sudah banyak menyebar di Jawa, sebagaimana nanti terbukti munculnya NII Aceh (Daud Buereueh) dan Sulawesi Selatan (Kahar Muzakkar). ${ }^{10}$ Banyak keributan yang ditimbulkan oleh ucapan-ucapan Soekarno ihwal masalah agama dan dasar ideologi negara. Sebagian golongan Muslim di Kalimantan Selatan menentang sikap Soekarno tentang peranan Islam dan penyebaran Marbaeinisme-nya jelas terbukti ketika dia tiba di Hulu Sungai. ${ }^{11}$ Puncaknya tercapai di Amuntai, ketika Soekarno menyampaikan pidato yang akan ditelaah dalam tulisan ini. Nama Amuntai kemudian menjadi bahan perbincangan setelah Soekarno berkunjung dan berpidato yang secara terangterangan menolak gagasan negara Islam. Soekarno dalam pidato yang dibacakannya pada 27 Januari 1953 itu, menyatakan bahwa gagasan negara Islam akan membuat Indonesia berada dalam jurang perpecahan, jika Islam dijadikan sebagai dasar negara, dia yakin bahwa Irian Barat akan menolak bergabung dengan Indonesia. Lewat orasi politiknya yang agitatif, Soekarno melansir paragraf yang diulangnya tiga kali: "Jangan mau, jangan mau, dan jangan mau!" Pidato tersebut dengan segera menghangatkan suhu politik Indonesia. Bantahan dan reaksi keras berdatangan dari ormas (organisasi masyarakat), partai dan tokoh-tokoh Islam, termasuk KH. A. Wachid Hasjim yang menjabat sebagai Ketua Umum PBNU dan KH. Isa Anshary, anggota DPP Masjumi. Soekarno bukan hanya dianggap mengadu domba umat Islam Indonesia, tetapi juga dianggap mencuri start kampanye, padahal saat itu Soekarno merupakan presiden konstitusional Republik Indonesia. ${ }^{12}$

\footnotetext{
${ }^{10}$ Deliar Noer, "Piagam Jakarta," dalam majalah Tempo Edisi 36/XXX 05 November 2001.

${ }^{11}$ Perlu dicatat di sini bahwa dari sejumlah penduduk 248. 288 jiwa di kabupaten Hulu Sungai Utara (menurut sensus penduduk tahun 1966) adalah mayoritas beragama Islam. Lihat Anggraini Antemas, 17 Tabun Kabupaten Hulu Sungai Utara 1952-1969 dan Lintasan Sedjarah Perdjuangannja (Amuntai: PEMDA HSU, 1969), hlm. 24; Juga Anggraini Antemas, Lintas Sejarah Perjuangan Kemerdekaan dan Berdirinya Kabupaten Hulu Sungai Utara (Amuntai: PEMDA HSU, 2003), h. 1.

${ }^{12}$ Tentang biografi singkat Soekarno, lihat Muhammad Iqbal, "Soekarno: Bapak Revolusi Indonesia", dalam Iswara N. Raditya (ed.), 7 Bapak Bangsa (Jakarta: Rahzenbook, 2008), h. 253-318.
} 


\section{Peristiwa "Pidato Amuntai 1953"}

Menurut Sajuti Melik selaku wartawan yang ikut rombongan kepresidenan RI, Soekarno mengadakan rapat raksasa di Amuntai itu berkaitan dengan rencana perjalanannya berkeliling ke Kalimantan Selatan, Minahasa, Sangihe Talaud dan Sulawesi Selatan dari 25 Januari sampai 6 Februari $1953 .{ }^{13}$ Dalam kesaksian Yusni Antemas, ${ }^{14}$ sesungguhnya ini bukanlah kali pertama kunjungan Soekarno ke kota Amuntai. "Kedatangan Bung Karno pertama kali ke Amuntai adalah pada 1950," tutur Yusni. Dia yang pada 1952 bekerja sebagai pegawai di Jawatan Penerangan di kabupaten HSU sekaligus wartawan untuk harian lokal Indonesia Merdeka, mendapat informasi bahwa rombongan presiden RI berencana akan kembali mengunjungi Kalimantan Selatan.

Rupanya isi surat itu mendapat perhatian Bung Karno, dan tidak lama berselang ada kabar bahwa presiden akan segera datang ke Amuntai, tepatnya pada 27 Januari 1953. Mendapat kepastian itu, Yusni kemudian langsung

${ }^{13}$ Sajuti Melik, Negara Nasional atankah Negara Islam (Jogjakarta: Kedaulatan Rakjat, 1953), h. 20-2.

${ }^{14}$ Yusni Antemas yang lebih dikenal nama samarannya Anggraini Antemas lahir di Amuntai pada 22 April 1922. Pada masa penjajahan Jepang (1942-1945) ia menjadi Juru Penerang KEIMIN SIDUBO dan wartawan Borneo Shimbun sambil melukis dan menulis cerita untuk sandiwara amatir Fajar. Pada masa perjuangan (1945-9) Antemas bergabung dalam GERPINDOM dan menjabat sebagai sekretaris. Disamping itu ia aktif pula sebagai wakil pimpinaan redaksi harian Terompet Rakyat dan Menara Indonesia. Dalam Barisan Pelopor Pemberontak Kalimantan Indonesia (BPPKI) Antemas berpangkat Letnan Muda di bawah pimpinan Mayor Muhammad Yusni (mantan Pangdam X Lambung Mangkurat). Dalam kurun waktu (1953-1957) Antemas menjadi wartawan Harian Kalimantan Berjuang Banjarmasin, Harian Merdeka Jakarta, Harian Warta Berita Medan, Harian Indonesia Bandung, Harian Suara Rakyat Surabaya, Harian Nasional Yogyakarta, Majalah Gaya Surabaya, serta Harian Indonesia Merdeka Banjarmasin. Yusni sempat pula bekerja di Jawatan Penerangan Hulu Sungai Utara (1957-1964) dan menjabat sebagai Kabag Pers dan Publisistik. Selanjutnya (1964-1971) ia bekerja di Inspeksi Daerah Kebudayaan Kalimantan Selatan dan menjabat sebagai Perwakilan Hulu Sungai Utara dan selanjutnya dipromosikan menjadi Kepala Kantor Permuseuman Kalimantan Selatan. Dalam bidang politik ia pernah aktif sebagai Sekretaris Partai Serikat Kerakyatan Indonesia (SKI) di masa perjuangan dan ikut memimpin Partai Nasional Indonesia (PNI) yang kemudian mengantarkannya menjadi Anggota DPRD Tingkat I Kalimantan Selatan pada pemilu 1955. Lihat Ahmad Makkie (ed.), Apa \& Siapa Dari Utara Profil Dan Kinerja Anak Banua (Jakarta: Surya Garini, t.t.), h. 100-3.

${ }^{15}$ Wawancara penulis dengan Yusni Antemas (86 tahun) pada 26, 27, 28, 29 Oktober 2006 di Amuntai. 
mengadakan pertemuan dengan para tokoh masyarakat Amuntai lainnya, guna membicarakan apa yang harus dilakukan dan dipersiapkan dalam menyambut kedatangan Bung Karno tersebut. Sekitar Januari 1953, akhirnya Bung Karno dan rombongannya tiba di Banjarmasin, kemudian naik pesawat ke Warukin, Murung Pudak. Dari Warukin, perjalanan dilanjutkan ke arah Hulu Sungai lewat jalur darat. Kedatangan rombongan kepresidenan di Amuntai disambut dengan sangat meriah dan luar biasa. Bung Karno pasca turun dari mobil langsung dibawa ke mimbar podium dengan dipayungi payung khas dari Kalimantan Selatan. "Sampai-sampai anggota kepolisian yang berjaga semaput karena terlalu lama menunggu Bung Karno," ujar Antemas sambil tertawa. ${ }^{16}$ Dalam rangka penyambutan Soekarno, seluruh lapisan masyarakat Amuntai sudah banyak yang mempersiapkan poster-poster. Yusni pun tak mau ketinggalan pula. Dia dan Anang Abdul Muin kemudian berinisiatif untuk membuat sebuah spanduk dengan ukuran $3 \times 2$ meter yang dibuat dari kertas dan bertulisan warna merah. Pembuatannya pun dilakukan di kampung Karias (sekarang di Amuntai Gg. Gerpindom). ${ }^{17}$ Isi spanduknya singkat namun padat maknanya, "Minta Pendjelasan Negara Nasional atau Negara Islam?". Maksud Yusni menanyakan hal seperti itu karena pada waktu itu di kota Amuntai, banyak berdiri partai-partai yang berbasis (Islam) agama maupun nasional, seperti Masjumi, PNI, dan lain-lain, yang sering mewacanakan dengan hangat soal negara Nasional dan Islam. Mumpung Bung Karno akan datang ke Amuntai, lalu kesempatan untuk bertanya lewat spanduk itulah digagas dan dibuatnya, dengan harapan akan dijawab langsung oleh Bung Karno, agar masyarakat Amuntai mengerti dan tahu negara yang bagaimana RI ini, negara Islam atau negara Nasional. Yusni mengatakan, "Situasi dan kondisi dalam masyarakat Amuntai sendiri saat itu memang sedang panas dengan membicarakan, bahkan perang urang-saraf memperdebatkan perihal bentuk negara Indonesia, yakni antara negara Islam atau Nasional. Sebenarnya prapidato Amuntai tersebut, kami telah sering memberikan informasi lewat berita dan pamflet di Jawatan Penerangan tentang wacana konsep Negara Islam dan Negara Nasional." Yusni juga mengatakan bahwa Bung Karno saat itu

${ }^{16}$ Wawancara penulis dengan Yusni Antemas.

${ }^{17}$ Wawancara penulis dengan Yusni Antemas.

${ }^{18}$ Ihwal foto yang berisi gambar spanduk dan Soekarno dalam peristiwa "Pidato Amuntai 1953", lihat skripsi penulis: Muhammad Iqbal, "Menyulut Api di Padang Ilalang: Pidato Politik Soekarno di Amuntai 27 Januari 1953" (Yogyakarta: Universitas Negeri Yogyakarta, 2009). Tidak dipublikasikan. 
berusaha menyakinkan massa peserta rapat Amuntai 1953, bahwa dalam negara Nasional itu negara Islam boleh, malahan bisa terus eksis.

Menurut prosedur yang berlaku, izin pemasangan spanduk di lapangan Merdeka Amuntai (sekarang menjadi tugu monumen dekat Rumah Sakit Amuntai) tempat rapat raksasa di mana Soekarno hadir tersebut, harus diperiksa dulu secara ketat oleh pihak kepolisian. "Kami berdua kebingungan, khawatir akan dirazia dan disita. Sempat saya meminta seorang teman dari daerah Kota Raden untuk membawanya, tapi ia tidak berani, teman lain yang berdomisili di dekat pasar Amuntai pun juga tidak berani," ujar Yusni. Akhirnya dengan modal nekad, spanduk itu mereka bawa dengan diarak massal dari depan rumah Yusni di sungai Karias. Lanjutnya, "Saat acara dimulai, datang rombongan dari sungai Karias, tetapi saya sendiri tidak ikut rombongan tersebut karena telah tiba lebih dulu untuk meliput peristiwa ini di belakang panggung bersama banyak wartawan dari kota, bahkan dari Pulau Jawa”. Walhasil, spanduk yang dibawa bersama masyarakat dari kampung Karias menuju ke lapangan raksasa Merdeka secara berduyun-duyun, meskipun kedatangan mereka agak terlambat karena jarak yang cukup jauh. Presiden Soekarno saat itu telah memulai pidato lisannya, walau tidak begitu lama. Bung Karno pun menyuruh rombongan itu untuk segera bergabung, sedang di lapangan sedari subuh sudah dipenuhi oleh beribu-ribu warga yang datang dari seluruh pelosok. "Nah ini yang saya tunggu, mari-mari, bawa ke sini, bawa spanduk itu ke saya. Hari ini saya akan jawab langsung pertanyaan warga Amuntai ini," tegas Soekarno bersemangat. Lucunya, para polisi dan pihak keamanan tidak ada yang berani menegur rombongan tersebut perihal spanduk. Pidato lisan Soekarno ini kemudian diketik dengan mesin ketik steno oleh wartawan terkenal, Sajuti Melik. ${ }^{19}$

Selanjutnya dengan lantang Bung Karno berpidato di hadapan massa yang telah menjejali rapat raksasa Amuntai:

...Ada lagi jang bertanja: "Apa artinja, mana jang lebih baik maksudnja Negara Islam ataukah Negara Nasional?" Saudara-saudara begini, Bapak terangkan ja. Dengarkan! Kita menjusun Negara, dan kita inginkan satu Negara Nasional, oleh karena Negara ini harus meliputi segenap, sekudjur badanja Natie. Natie apa? Bangsa! Dari mana? Sabang sampai Merauke. Itu adalah Natie Indonesia. Oleh karena itu kita ingin mendirikan satu Negara Nasional. Agamanja bagaimana? Ada jang Buddha-Shiwa, ada jang agama Islam, ada jang Kristen, ada jang belum beragama. Tetapi kalau kita 
mengatakan, saudara-saudara, hanja didirikan Negara Islam, Saudarasaudara di Ambon tak mau ikut! Terus terang, ketahuilah saudara-saudara bahwa sebagian besar dari rakyat Indonesia benar beragama Islam, tetapi sebagian lagi tidak beragama Islam, Irian Barat tidak Islam, sebagian dari Ternate tidak Islam, Sulawesi Utara tidak Islam, Sulawesi setengah-Sulawesi Tengah-Toradja tidak Islam. Bahkan di Kalimantan ini dibagian-bagian tengah Saudara-saudara, Dajak, tidak Islam. Ada jang sudah kirim surat kepadaku: "Pak, kalau Negara Republik Indonesia ini dinamakan Negara Islam, kami tidak mau ikut. Lebih baik kami mengadakan Negara sendiri, Negara Indonesia Timur sendiri”.

Soekarno juga mengatakan dalam pidatonya,"Apakah Saudara mau demikian? Satu Negara sonder sebagian besar dari Sulawesi, sonder Bali, sonder sebagian besar Sumbawa, sonder Sumba, sonder Flores, sonder Timor, sonder Aru, sonder Kai, sonder Savu, sonder Roti, sonder Ambon, sonder nan-Saparua, sonder Laut Nusalaut, sonder Seram, sonder sebagian dari pada Sulawesi Utara, sonder sebagian dari Ternate? Maukah Saudarasaudara demikian? Saudara-saudara Bapakpun tidak mau! Maka oleh karena itu djanganlah kita berebut kata, Negara Islamkah atau Negara Nasionalkah. Tanamkan didalam dadamu; 'Kita mau menghendaki Negara Nasional jang meliputi sekudjur badannja Natie, dari Sabang sampai ke Merauke", tegasnya. ${ }^{20}$

Pidato lisan Soekarno di hadapan rakyat Amuntai, memberi kesan dan kenangan yang berbeda-beda bagi mereka yang berkesempatan hadir pada rapat raksasa tersebut. H. Syafriyansyah ${ }^{21}$ misalnya, dia yang ikut hadir pada peristiwa

${ }^{20}$ Lihat Mimbar Penerangan, Tahun IV, No. 2, Edisi Februari 1953.

${ }^{21}$ Wawancara penulis dengan H. Syafriyansyah (75 tahun) pada 4 dan 6 November 2006 di Banjarmasin. H. Syafriansyah, kelahiran Anjir Serapat pada 8 Agustus 1931 sejak muda sudah bergaul dengan warga Hulu Sungai Utara. Putera ke empat dari pasangan H. Mastur dan $\mathrm{Hj}$. Amnah ini pada masa mudanya aktif berorganisasi khususnya di lingkungan NU. Dia juga menjadi santri di Ponpes Rakha Amuntai. Syafriansyah adalah anggota DPR-RI dari Fraksi PPP (periode 2004-2009). Perjalanan kariernya sebagai Kepala Sekoah Rakyat NU di Amuntai (1951-1955), Wakil Kepala Sekolah Tsanawiyah di Haruai (1955-1956), Guru pada PGA NU di Amuntai (1958-1960), Kepala Tata Usaha dan Pengasuh Panti Asuhan Budi Rahayu Amuntai (1958-1966), Pegawai Negeri Sipil pada Kantor Departemen Agama Kabupaten Hulu Sungai Utara (1963-1981), Anggota DPRD Tingkat II Hulu Sungai Utara (1964-1966), Anggota Badan Pemerintah Harian Kabupaten Hulu Sungai Utara (1966-1971) bidang kesejahteraan Rakyat dan Pembangunan, Dosen Luar Biasa pada Fakultas Ushuluddin Amuntai (1969-1979), Wakil Dekan dan Dosen pada Fakultas Tarbiyah Rakha Amuntai (1975-1985), Guru pada Pondok 
ini, dapat merasakan suasana yang semarak, riuh dan penuh sesak karena dijejali rakyat yang hadir. "Saya saat peristiwa Pidato Politik Soekarno di Amuntai tahun 1953 tersebut ikut hadir dan berada di posisi menghadap depan panggung bersama dengan kawan-kawan sekolah mendengar pidato Bung Karno, suasana lapangan telah dipenuhi massa rakyat yang berjejalan", kenangnya. H. Syafriyansyah bercerita mengingat "Peristiwa Pidato Amuntai 1953":

Saat itu yang menjadi heboh adalah spanduk buatan wartawan Yusni Antemas, dan kawan-kawan, yang isinya, Minta Penjelasan: Negara Nasional atau Negara Islam. Seperti yang kita ketahui bersama, tahun 1950-an, partaipartai Islam sangat terobsesi untuk mendirikan negara Indonesia merdeka yang berasaskan Islam. Salah satu tugas dari Konstituante adalah membentuk undang-undang negara. Jelas saat ini di Indonesia tidak berlaku UUD 1945, sebaliknya yang berlaku hanya UUD Sementara 1950. Saat itu umur saya 22 tahun (lahir 1931). Saya sangat memahami sekali pidato itu. Situasi dan kondisi masyarakat Amuntai yang sangat religius saat itu menghadapi pemilu 1955, jelas arahannya ingin memihak partai-partai Islam. Nah, sebenarnya, ada siasat dari golongan Nasionalis Netral Agama untuk memanfaatkan momentum tersebut, dan ternyata benar, Bung Karno menjawab dan sesuai dengan jawaban yang diinginkan oleh pihak PNI (Yusni Antemas, dan kawan-kawannya). Sebaliknya, warga Amuntai yang fanatik dengan Islam banyak yang tidak menyukai jawaban dalam pidato Bung Karno itu. ${ }^{23}$

Pesantren Rakha Amuntai (1978-1986) dan sebagai Guru pada PGA Negeri di Amuntai (19801982), Anggota DPRD Tingkat I Kalimantan Selatan/Wakil Ketua Komisi E Bidang Kesra (1982-1987), Anggota DPRD Tingkat I Kalimantan Selatan/Ketua Komisi C Bidang Ekonomi (1987-1992), Wakil Ketua DPRD Tingkat I Kalimantan Selatan (1992-1997), Anggota DPD RI (1997-1999), Anggota DPR RI (1999-2004), Anggota DPR RI (2004-2009). Syafriansyah pernah menjadi Sekretaris Partai NU Kabupaten Hulu Sungai Utara (1958-1973), Wakil Ketua DPW Partai Persatuan Pembangunan Kalimantan Selatan (1984-1990), Ketua DPW Partai Persatuan Pembangunan Kalimantan Selatan (1990-1995) dan (1995-1998), Wakil Sekretaris Jenderal DPP Partai Persatuan Pembangunan Pusat (1998-2002) dan (2002-2006), Anggota Dewan Pertimbangan Partai Persatuan Pembangunan Pusat. Lihat Eka Dolok Martimbang, Profil H. Syafriansyah, Pikiran dan Prilaku Islami (Jakarta: Mardi Mulyo, 2003).

${ }^{22}$ Ihwal gambar massa yang hadir pada peristiwa "Pidato Amuntai 1953", lihat skripsi penulis.

${ }^{23}$ Wawancara penulis dengan H. Syafriyansyah. 
Selain itu, H. Syafriyansyah juga menuturkan peristiwa menarik yang pasca-"Pidato Amuntai 1953" tersebut. Kurang lebih beberapa bulan pasca peristiwa "Pidato Amuntai 1953", Partai Masyumi Cabang Amuntai mengundang tokoh nasionalnya yakni ulama sekaligus politikus $\mathrm{KH}$. Muhammad Isa Ansyari untuk berpidato di depan Masjid Raya Amuntai. Isinya menghantam balik seluruh isi pidato Bung Karno. H. Syafriyansyah mengatakan, "Sejarah telah membuktikan bahwa Bung Karno dan Isa Ansyari adalah dua orator yang luar biasa. Sangat berkesan dan dahsyat. Kami saja para pemuda pesantren saat itu sangat mengidolakan dan sering meniru mereka dalam berpidato di pelbagai moment. Memang sangat menggelora sekali semangat revolusi di tahun 50-an. Protes Isa Anshary tersebut berlanjut terus. Menurut riwayat, ketika dia melakukan kampanye Pemilihan Umum 1955 untuk Partai Islam Masjumi di Kalimantan Selatan, ia sengaja datang ke Amuntai dan mencari mimbar yang digunakan oleh Bung Karno untuk berpidato seraya mengulangi kembali penolakannya terhadap pidato yang pernah diucapkan oleh Bung Karno di tempat yang sama," tandasnya. ${ }^{24}$

Kesaksian yang berbeda dituturkan oleh Tuan Guru H. Napiah. ${ }^{25}$ Menurut ulama kharismatik asal HSU ini, bahwa massa rakyat yang hadir pada

${ }^{24}$ Penulis tidak berhasil menemukan data tertulis yang merekam peristiwa kedatangan dan komentar dari Isa Anshary ini selama kunjungannya di Amuntai. Namun, hampir semua narasumber yang diwawancarai oleh penulis mengatakan bahwa Isa Anshary memang pernah datang ke Amuntai untuk kampanye pemilu 1955.

${ }^{25}$ Tuan Guru H. Napiah (86 tahun) merupakan rekan seangkatan dari Tuan Guru Abdul Muthalib M., Tuan Guru Ahmad Mansur, dan Tuan Guru Idham Chalid. H. Napiah lupa apakah Tuan Guru H. Idham Chalid juga ikut hadir pada "Peristiwa Pidato Amuntai 1953". Dalam otobiografinya, Idham tidak pernah menyebut sama sekali peristiwa sejarah yang cukup penting bagi rakyat Banjar ini. Selanjutnya lihat Arief Mudatsir Mandan (ed.), Napak. Tilas Idham Chalid.Tanggung Jawab Politik NU dalam Sejarah (Jakarta: Pustaka Indonesia Satu, 2008); Lihat juga Ahmad Muhajir, Idham Chalid: Guru Politik Orang NU (Yogyakarta: Pustaka Pesantren, 2007). Nafiah yang biasa dipanggil Antaya itu, lahir di Amuntai pada 27 Ramadhan 1343 (1922). Ayahnya bernama H. Djamal yang merupakan pedagang yang sangat memerhatikan pendidikan anak-anaknya. Pada 1929 Nafiah kecil masuk Sekolah Rakyat 5 tahun. Sambil sekolah ia berjualan di depan rumah. Setelah tamat sekolah (1934), dia diajak ayahnya ikut berdagang selama lebih kurang dua tahun. Pada 1937 Nafiah dibawa ayahnya pergi haji dan sepulang dari tanah suci ia masuk sekolah di Pesantren Rasyidiyah Khalidiyah Amuntai dan hanya sempat dua tahun belajar di sana. Pada 1939 Nafiah berangkat meninggalkan kampung halamannya dan belajar di Pondok Modern Gontor Ponorogo. Dia menjadi siswa Madrasah Tsanawiyah sampai 1943. Sepulang dari Gontor, dia mengaji pada Tuan Guru H. Abdul Hamid Sungai Banar dan Tuan Guru H. Chalid Tangga Ulin. Karier di bidang pendidikan dimulai 
acara itu bukan saja berasal dari Amuntai, tapi juga dari kota-kota lainnya seperti dari Barabai, Tanjung, Kandangan. Tuan Guru H. Napiah menuturkan sebagai berikut:

Saya hadir saat itu. Lokasi peristiwa itu sekarang namanya Lapangan Pahlawan HSU. Waktu itu, H. Idham Chalid, ulama sekaligus politisi Indonesia asal Kalsel masihlah sangat muda. Saya ini sahabat karib H. Idham Chalid. Bisa dibilang pendukung setia dia. Warga Amuntai saat itu ribuan yang datang pada acara tersebut. Dari luar kabupaten, yakni Barabai, Tanjung, Kandangan, dan sebagainya. Umur saya itu kira-kira 30 tahun. Seingat saya isi pidatonya tentang persatuan dan kesatuan. Saya saat itu telah aktif di organisasi Musyawaratut Tholibin cabang Amuntai, kemudian baru masuk Nahdlatul Ulama (sebagai simpatisan) dan berlanjut aktif ke partai Masjumi. Waktu dilaksanakan pidato Bung Karno sekitar jam 10 pagi, dan durasinya tidak lebih dari 1 jam saja. Reaksi warga Amuntai biasa-biasa saja pasca peristiwa itu, malahan senang atas kedatangan Bung Karno ke Amuntai. ${ }^{26}$

Kesaksian ihwal waktu dan durasi pelaksanaan dari "Pidato Amuntai 1953” yang hampir mirip seperti yang dituturkan oleh Tuan Guru H. Napiah, penulis dapati dari cerita $\mathrm{Hj}$. Khairunnisa (71 tahun) dan Hj. Nur Laila (71 tahun). ${ }^{27}$ Menurut mereka, rombongan kepresidenan sampai ke lapangan Merdeka antara jam 9 sampai 10 pagi. "Kami masih ingat, udara saat itu tidaklah terlalu panas oleh terik matahari karena masih pagi, yang bikin panas itu malah kerumunan massa yang ikut rapat berdesak-desakan," tambah mereka berdua menegaskan. Tidak semua rakyat Amuntai yang ikut rapat dapat mengingat bahkan mengetahui isi pidato Bung Karno, yang memberikan

ketika menjadi staf pengajar di Madrasah Sulamun Najah Telaga Silaba (1943), Madrasah Rasyidiyah Pekapuran (1944-1946), Madrasah Normal Islam (1947-1951). Ia termasuk salah seorang pendiri Perguruan Normal Islam (1951), Ketua Yayasan Rasyidiyah Khalidiyah (1955). Tuan Guru H. Nafiah sempat menjadi anggota DPRD Tingkat II Hulu Sungai Utara (19641988). Beliau termasuk orang pertama di Indonesia yang mempelopori usaha penyelenggaraan Biro Perjalanan Haji dan Umrah. Lihat Ahmad Makkie (ed.), Apa \& Siapa Dari Utara Profil Dan Kinerja Anak. Banua (Jakarta: Surya Garini, t.t.), h. 71-2.

${ }^{26}$ Wawancara penulis dengan Tuan Guru H. Napiah (86 tahun) pada 27 Oktober 2006 di Amuntai, ia meninggal dunia pada 2007 di Amuntai.

${ }^{27}$ Wawancara penulis dengan $\mathrm{Hj}$. Khairunnisa (71 tahun) dan Hj. Nur Laila (71 tahun) di Amuntai pada 4 Oktober 2008. Mereka berdua sehari-hari bekeja sebagai petani sekaligus ibu rumah tangga. Lahir di Amuntai, namun tanggal lahir keduanya tidak diketahui secara pasti. Umur narasumber penulis cantumkan sesuai pengakuan dan perkiraan narasumber sendiri. 
jawaban atas pertanyaan spanduk milik Yusni dan kawan-kawan tersebut. Yusran (84 tahun), bersama Abdul Mutholib (82 tahun), dan Zunaidi (86 tahun), yang ikut menyaksikan "Peristiwa Pidato Amuntai 1953" mengatakan bahwa mereka telah lupa apa saja isi pidato Bung Karno:

Kami bertiga dan teman-teman seangkatan dulu datang ke lapangan tersebut untuk melihat sosok Bung Karno, yang dulu lucunya banyak orang Amuntai sebut dengan "raja" bukan sebagai "presiden". ${ }^{28}$ Seingat saya, kehadiran Bung Karno waktu itu merupakan kedatangannya yang kedua. Dia waktu itu memakai seragam kebesarannya dengan gagah, memakai tongkat yang katanya baru didapat dari Martapura. Penuh dengan aura kharismatis dan berwibawa. Juga memakai kacamata hitam. ${ }^{29}$

Hiruk-pikuk rakyat yang menghadiri rapat raksasa Amuntai bukan hanya dihadiri oleh kaum pria. Ibu-ibu, dan para gadis pun tidak mau kalah dengan bersemangat ikut menonton dan mendengarkan pidato Presiden Soekarno. Mereka bercampur-baur dengan riuhnya peserta rapat terbuka itu. Hj. Satimah (90 tahun) bersama adiknya, Hj. Fatimah (83 tahun), dan adik sepupunya, $\mathrm{Hj}$. Zubaedah (86 tahun) ${ }^{30}$ sangat ingat bagaimana suasana rapat raksasa Amuntai itu. "Kami bertiga berangkat bahkan mengiringi rombongan mobil Bung Karno bersama-bersama dengan orang kampung lainnya hingga menuju lapangan Merdeka. Bung Karno melambai-lambaikan tangannya kepada massa dengan sangat ramah dan hangat," kenang mereka. Uniknya, mereka mengaku tidak mengerti apa yang dibicarakan oleh Bung Karno saat berpidato. Lanjut mereka bergurau, "Kami hanya ikut bertepuk-tangan dan bersorak-sorak dengan gembira saja jika melihat massa yang lain melakukannya," ujar $\mathrm{Hj}$. Satimah dan keluarga. Rupanya bukan saja orang dewasa yang hadir dalam

${ }^{28}$ Istilah "raja” (atau "sultan") yang masyarakat Amuntai gunakan untuk menyebut Bung Karno yang sebenarnya adalah seorang presiden ini, sama persis dengan istilah rakyat Jawa gunakan untuk Bung Karno. Seperti yang diceritakan Pramoedya Ananta Toer berikut ini, “... dengan gembira mereka membawa berita itu ke desa-desanja masing-masing: "Sekarang radja kita seorang radja Djawa, seorang radja dengan pici". Lihat Pramoedya Ananta Toer, "Dia Jang Menjerah", dalam Tjerita dari Blora (Djakarta: t.p., 1952), h. 227.

${ }^{29}$ Wawancara penulis dengan Yusran (84 tahun), Abdul Mutholib (82 tahun), dan Zunaidi (86 tahun) di Amuntai pada 3 Oktober 2008. Mereka sehari-hari bekeja sebagai petani.

${ }^{30}$ Wawancara penulis dengan $\mathrm{Hj}$. Satimah (90 tahun), Hj. Fatimah (83 tahun), dan $\mathrm{Hj}$. Zubaedah (86) di Amuntai pada 4 Oktober 2008. Mereka sehari-hari bekeja sebagai petani sekaligus ibu rumah tangga. Lahir di Amuntai, namun tanggal lahir ketiganya tidak diketahui secara pasti. Umur narasumber penulis cantumkan sesuai pengakuan dan perkiraan narasumber sendiri. 
memeriahkan "Peristiwa Pidato Amuntai 1953" itu, bahkan anak-anak juga ikut hadir menyemarakkan peristiwa bersejarah tersebut. Menurut kesaksian $\mathrm{H}$. Badrun (70 tahun) dan H. Abdul Muchied (69 tahun), mereka saat itu bertugas sebagai siswa Sekolah Rakjat (SR) yang ditugasi untuk membawa dan melambaikan bendera Merah-Putih-terbuat dari kantong plastik sablon-guna memeriahkan penyambutan rombongan kepresidenan ke atas panggung. "Kami berdua dan kawan-kawan satu sekolah beregu buat menyambut Bung Karno dengan melambai-lambaikan bendera Merah-Putih Indonesia sebagai simbol kehangatan dari anak-anak sekolahan Amuntai," ujar mereka. Ketika ditanya soal apa isi pidato Bung Karno pada saat itu, mereka sama sekali tidak mengerti perihal tersebut. ${ }^{31}$

Kenangan manis mengikuti "Peristiwa Pidato Amuntai 1953" juga dialami oleh H. Asy'ari Yurnie. "Ikut bergabung di lapangan bersama temanteman, saya hanya ingin melihat secara langsung wajah dari Bung Karno, yang katanya gagah, penuh kharismatik, dan seorang yang orator," ujar salah satu tokoh pejuang Angkatan 45 dan salah satu perintis kemerdekaan di daerah Amuntai, HSU ini. H. Asy'ari Yurnie mengatakan:

Walaupun hanya sebentar, saya cukup puas dan bersyukur, bisa hadir. Saya masih ingat saat itu, kenapa Bung Karno tiba-tiba isi pidatonya membicarakan masalah tersebut, karena pada waktu itu Yusni Antemas dan rombongannya membawa spanduk besar isinya minta penjelasan apakah negara nasional atau negara Islam. Bung Karno setelah berpidato, memperoleh sekitar 20 buah lukisan, salah satu lukisan yang sangat bersejarah adalah "lukisan Pembumihangusan daerah Paliwara Amuntai" karya pelukis Y. Hamdie, serta diserahkan kepada Bung Karno sebuah tongkat, dimana hulunya berlapis dengan emas murni dengan lukisan peta Kalimantan dan letak kota Amuntai ditandai dengan sebuah intan permata. ${ }^{32}$

${ }^{31}$ Wawancara penulis dengan H. Badrun (70 tahun) dan H. Abdul Muchied (69 tahun), di Amuntai pada 3-4 Oktober 2008. H. Badrun (70 tahun) sehari-hari bekeja sebagai pedagang di pasar Amuntai, sedangkan H. Abdul Muchied (69 tahun) merupakan anggota DPRD di kabupaten HSU (periode 2004-2009) dari fraksi Partai Persatuan Pembangunan (PPP). Lahir di Amuntai, namun tanggal lahir keduanya tidak diketahui secara pasti. Umur narasumber penulis cantumkan sesuai pengakuan dan perkiraan narasumber sendiri.

${ }^{32}$ Serambi Ummah, no. 084, edisi 15-21 Juni 2001. 


\section{Munculnya Pelbagai Reaksi}

Pidato politik Soekarno di Amuntai pada 27 Januari 1953 menjadi bahan perbincangan selama berbulan-bulan. Van Dijk mengatakan pada mulanya pidato Soekarno yang disampaikan di sebuah pojok terpencil di Indonesia, semula tidak menarik banyak perhatian, namun kemudian sesudah isinya diketahui lebih luas, timbul gelombang protes. ${ }^{33}$ Gelombang protes ini bermula dari berita yang diinformasikan oleh Antara yang berbunyi sebagai berikut:

Mendjawab sembojan jang bertanja "Indonesia Negara Nasional atau Negara Islamkah?”, Presiden Sukarno di Amuntai menjatakan, bahwa Negara jang kita susun dan jang kita ingini ialah Negara Nasional jang meliputi seluruh Indonesia. Kalau kita dirikan Negara berdasarkan Islam, maka banjak daerah2 jang penduduknja tidak beragama Islam akan melepaskan diri, misalnja: Maluku, Bali, Flores, Timur, Kai, Sulawesi. Dan djuga Irian Barat jang belum masuk wilajah Indonesia tidak akan mau ikut dalam Republik.

Presiden Sukarno menegaskan, ia tidak mau susunan Negara Indonesia dimana tidak seluruh bagian2 masuk didalamnja. Diandjurkan, supaja kita tidak berebutan kata. Negara Nasional jang berdasarkan Pantjasila tidak bertentangan dengan Islam. Dalam hubungan itu Presiden menjatakan, bahwa ia sendiri adalah beragama Islam, dan kalau ada golongan di Indonesia jang menentang Islam, maka ialah jang pertama-tama akan mempertahankan Islam.

Negara Nasional jang kita susun adalah meliputi seluruh wilajah Indonesia dan dengan penduduk jang bermatjam-matjam agamanja. ${ }^{34}$

Boyd Compton menyatakan bahwa reaksi yang cepat segera muncul dari tokoh-tokoh terpandang, terutama dari kelompok-kelompok yang isinya "menyesalkan" bahkan "terkejut" atas isi pidato Bung Karno di Amuntai tersebut. ${ }^{35}$ Pelbagai reaksi pun akhirnya tidak bisa terbendung. M. Isa Anshary adalah yang pertama-tama menyatakan reaksinya secara terbuka. ${ }^{36}$ Ia

\footnotetext{
${ }^{33}$ Cees van Dijk, h. 242.
}

${ }^{34}$ Antara, 29 Januari 1953.

${ }^{35}$ Boyd Compton, Kemelut Demokrasi Liberal: Surat-Surat Rahasia, a.b.: Hamid Basyaib (Jakarta: LP3ES, 1992), h. 122.

${ }^{36} \mathrm{KH}$. Muhammad Isa Anshary lahir di Maninjau, Sumatera Tengah pada 1 Juli 1916. Pada 7 Desember 1949, Isa menjadi ketua umum pusat pimpinan Persatuan Islam (Persis). Dia dijuluki sebagai Singa Mimbar, sebab dalam setiap berdakwah, gayanya selalu berapi-api dan 
menyatakan, "Pidato Presiden Soekarno itu djiwa dan semangatnja adalah tidak demokratis dan tidak konstitusionil". ${ }^{37}$ Dalam nota protesnya kepada pemerintah-dalam hal ini kepada Perdana Menteri Wilopo dan Wakil Perdana Menteri Prawoto Mangkusasmito-pada 31 Januari 1953, antara lain ia menilai pidato tersebut "bukan suatu kebidjaksanaan jang dapat dihargakan, karena berisi 'penentangan' terhadap suatu ideologi Islam jang dianut oleh sebagian terbesar dari warga negara Indonesia". Nota protes yang disampaikan oleh M. Isa Anshari adalah dalam kapasitasnya sebagai anggota parlemen, di samping dia juga sebagai ketua Masjumi Jawa Barat. ${ }^{38}$ Protes juga datang dari Pengurus Besar Nahdlatul Ulama (PBNU) pada 4 Februari 1953, dewan tertinggi partai Islam Perti pada 5 Februari 1953, pucuk pimpinan Gerakan Pemuda Islam Indonesia pada 12 Februari 1953, dan Pengurus Besar Persatuan Islam pada 16 Februari 1953. ${ }^{39}$ PBNU dalam suratnya yang ditandatangani oleh KH. A. Wahid Hasjim dan ditulis oleh A. Sjahri antara lain menyatakan:

Djikalau ternjata benar apa jang terdapat dalam berita perdjalanan Bapak itu, maka kami menjetudjui djalan fikiran Saudara Isa Anshary... karena pernjataan bahwa Pemerintahan Islam tidak dapat memelihara persatuan bangsa dan akan mendjauhkan Irian, menurut pandangan hukum Islam adalah merupakan perbuatan munkar jang tidak dibenarkan sjariat Islam dan wadjib bagi tiap-tiap orang Muslim menjatakan ingkar atau tidak setudjunja.

Selandjutnja diharapken, agar presiden tidak mentjampurkan diri pada pergeseran-pergeseran politik dan persoalan partai-partai serta pertentangan ideologi, terutama antara kaum Islam dan fihak anti Islam. Dengan demikian maka kepala negara akan tetap berdiri di tengah-tengah, dan tidak berat sebelah. ${ }^{40}$

Pernyataan dewan tertinggi Partai Islam Perti (ditandatangai oleh $\mathrm{H}$. Siradjudin Abbas) menilai "pidato Presiden sekali ini bertendens adu domba" dan "menggelisahkan umat Islam". Pada bagian lain dikemukakan pula, "Dasar Negara Republik Indonesia jang akan datang, seharusnja diserahkan kepada Dewan Konstituante setjara demokratis, bukan pada fikiran-fikiran dan pendapat-pendapat Presiden seorang diri". Sementara itu PP GPII dalam

memiliki lidah yang tajam. Isa juga seorang penulis yang handal. Di samping itu, Isa juga seorang politisi dari Partai Masjumi. Selanjutnya lihat Arsip Persis, Tahun 1953.

${ }^{37}$ Sin Po, 11 Maret 1953.

38 Aneta, 2 Februari 1953.

39 Aliran Islam, No. 46, Tahun VII, Edisi Maret 1953.

40 Aliran Islam, No. 46, Tahun VII, Edisi Maret 1953. 
suratnya (ditandatangani oleh A. Haryono, Ketua dan Firdaus AN, Wakil Sekretaris) kepada presiden antara lain menyatakan, "Kini Bapak telah menanam benih-benih separatisme kepada rakjat ..... Dan ternjata dengan itu Bapak telah menjatakan memihak kepada segolongan rakjat jang tidak setudju dengan ideologi Islam. ${ }^{41}$ Dalam buku Persoalan Negara Islam, Saleh Suaidy mengemukakan pendapatnya:

Bagaimanapun djuga, baik muslim maupun non atau anti Islam tidak dapat memungkiri kenjataan, bahwa Islam karena sedjarahnja dan karena sisinja telah merupakan satu aspek atau anasier kebudjajaan jang berpengaruh dalam kehidupan dan tjara berfikir dan falsafah pandangan hidup sebagian terbesar bangsa Indonesia. Maka, tidak usah sebagai muslim, bukan muslim pun, tetapi sebagi politisi sadja, rasanja sudah selaiknja dalam menentukan isi, tjorak dan bentuk negara jang dikendakinja di Indonesia ini harus memperhatikan faktor kebudajajaan jang berpengaruh ini kalo ia hendak mendapat backing dan bentukan negara itu kokoh disokong oleh rakjat jang terbanjak. Apalagi sebagai Muslim, sebagai Katolik atau Protestan pun, kalo menghadapi kenjataan demikian, kalo mengindahkan faktor itu dan kehendak rakjat jang terbanjak itu.

Kalo Bung Karno mengatakan bahwa negara nasional tidak bertentangan dengan Islam, maka itu ada benarnja ada pula tidak benarnja. Sebab negara nasional itu ada dua macam. Negara nasonal jang berdasar dan berhukum Islam dan Negara Nasional jang tidak berhukum Islam, jang tidak berdasar dan berdasar Islam dengan sendirinja bertentangan dengan Islam. ${ }^{42}$

Lalu bagaimanakah reaksi pers terhadap pidato Soekarno di Amuntai tersebut? Reaksi pers non-Islam lebih tenang, agaknya memperlihatkan keengganan menyerang kelompok-kelompok Islam secara terbuka mengenai masalah agama. Koran Merdeka mengajak pembacanya tidak terlalu memperdulikan pidato itu, "Sebab sebagai orator, presiden tak dapat senantiasa menjadari akibat-akibat dari apa jang ia katakan". Merdeka kemudian menekankan bahwa peran Presiden Soekarno sebagai pemimpin NKRI tak

${ }^{41}$ Endang Saifuddin Anshari, Piagam Jakarta 22 Juni 1945 dan Sejarab Konsensus Nasional antara Nasionalis Islami dan Nasionalis "Sekular" tentang Dasar Negara Republik Indonesia 1945-59 (Bandung: Pustaka, 1983), h. 63.

${ }^{42}$ Muhammad Saleh Suaidy, Persoalan Negara Islam (Jakarta: Perbaikan, 1953), h. 56-7. Dikutip dari Abdurrahman, "Peristiwa Amuntai 1953 dan Pengaruhnya Terhadap Perkembangan Politik di Indonesia". Banjarmasin: makalah diskusi redaksi Banjarmasin Post pada Sabtu, 19 September 1998, h. 10-1. 
sama dengan para pemimpin negara lain, entah itu Presiden Perancis, atau Ratu Negeri Belanda. Redaksi merasa sangat sulit untuk melukiskan posisi Soekarno dengan "kata-kata dingin", menyiratkan bahwa posisi ini tidak dapat diukur secara ketat atau, begitulah tentunya dibatasi secara tegas. ${ }^{43}$ Koran sosialis Jakarta, Pedoman mengecam Bung Karno bukan lantaran tidak menghargai Islam dalam politik, namun lebih karena keprihatinannya yang pekat dan tak putus tentang posisi istimewa Soekarno dalam negara Indonesia. Tetapi Partai Sosialis Indonesia (PSI) melangkah sendirian, gelisah akan nasionalisme emosional Soekarno dan PNI, gusar akan tujuan taktik-taktik kaum komunis, PSI menjadi sangat sering sebaris dengan Masjumi, partai konservatif Islam yang pada akhirnya harus pula berurusan dengan macam-macam persoalan. ${ }^{44}$

Bagaimana sikap pimpinan Masjumi sendiri tentang masalah ini? $\mathrm{M}$. Natsir serta para pemimpin utama Masjumi tidak menyuarakan sanggahan keras. Sukiman mengemukakan bahwa masalah itu dapat diselesaikan secara Islam dalam rangka persaudaraan Islam. ${ }^{45}$ Sukiman mengatakan ini kepada para anggota Masjumi di Medan pada 2 Maret 1953. Meskipun demikian, Masjumi sendiri menganggap pidato Soekarno itu sebagai satu hal serius. Partai ini berpendapat bahwa kewajiban tiap muslim untuk menghilangkan salah pengertian tentang Islam. ${ }^{46}$ Kelompok Nasionalis Netral Agama pada gilirannya membela Soekarno. Kelompok Nasionalis Netral Agama membantah bahwa atas dasar hak prerogatif Presiden Soekarno sebagai pemimpin revolusi dan pemberi ilham rakyatnya di samping sebagai Kepala Negara yang konstitusional. Selanjutnya Kelompok Nasionalis Netral Agama menjadikan M. Isa Anshary sebagai tumpuan serangannya, dan orang terakhir ini pada gilirannya membalas dan mengulangi protesnya. Di lain pihak, Natsir dan Sukiman, para pemimpin utama Masjumi, mencoba memperkecil isu ini dengan jalan meyakinkan rakyat bahwa perbedaan pendapat ini akibat dari kekacauan istilah (a confusion of terms) dan masalah ini adalah masalah intern masyarakat Muslim, dan tidak usah dibicarakan di luar lingkungannya secara berlebihlebihan. ${ }^{47}$ Tidak mau ketinggalan moment pemberitaan, sebuah surat kabar dari negara Belanda, Niews Rotterdamsch Courant (NRC), pun juga memuat berita tentang pidato Soekarno yang katanya menghebohkan gara-gara sebuah

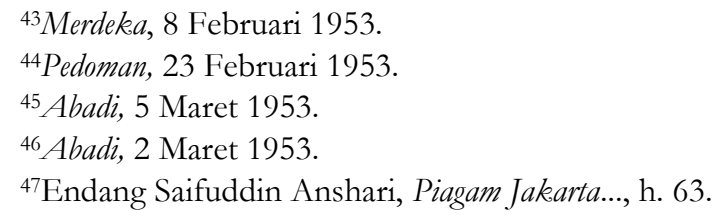


spanduk, yang isinya hanyalah meminta sebuah penjelasan saja. Menurut NRC, "Presiden Soekarno terlalu premateur telah membakar-bakar semangat juang rakyat Amuntai ke arah Negara Nasional di luar kompetensinya sebagai seorang presiden. Kalau bicara di Amuntai seharusnya Bung Karno agak berhati-hati," ${ }^{48}$ demikian komentar koran NRC.

Reaksi secara lokal datangnya dari pimpinan Masyumi Kalimantan Selatan. Harian Indonesia Merdeka sebuah koran lokal yang terbit di Banjarmasin pada 8 Februari 1953 memberitakan, bahwa Masjumi Kalimantan Selatan adalah satu partai yang menyebut dengan gusar kata-kata Soekarno ini. Pidato itu mereka nyatakan propaganda berat sebelah, karena tidak dikemukakan pilihan alternatif suatu partai politik dengan ideologi Islam atau dengan cita-cita mendirikan Negara Islam. ${ }^{49}$ Namun, sayangnya kita tidak banyak mengetahui bagaimana reaksi dari organisasi Islam lainnya pada tingkat lokal termasuk sikap dari rakyat di Hulu Sungai Utara sendiri. Selain pelbagai protes, dijumpai pula pihak yang mendukung Bung Karno. Sabilal Rasyad dalam harian Merdeka tertanggal 6 Februari 1953 menyatakan pembelaannya terhadap pidato Bung Karno. Menurut Rasyad, daya penarik rakyat total berjuang mempertahankan kemerdekaan adalah karena kemerdekaan ini milik nasional bukan milik sementara golongan dalam masyarakat bangsa Indonesia. ${ }^{50}$ Dukungan berikutnya adalah dari Sajuti Melik yang ketika itu lebih dikenal sebagai wartawan pribadi presiden. Dalam waktu tidak sampai tiga bulan pasca Pidato Amuntai, ia menerbitkan sebuah pamplet yang berjudul "Negara Nasional ataukah Negara Islam". ${ }^{11}$ Dalam tulisan ini dia menandaskan bahwa Soekarno dengan pidatonya itu bukan cuma menebak-nebak situasi masa depan, melainkan bicara berdasarkan bukti yang ada. Sejak 1945, presiden sudah menerima banyak sekali pernyataan dari daerah-daerah non Islam, yang menegaskan bahwa mereka akan mendukung pemisahan seandainya negara Islam terbentuk. ${ }^{52}$

48Anggraini Antemas, Lintas Sejarah Perjuangan Kemerdekaan dan Berdirinya Kabupaten Hulu Sungai Utara (Amuntai: PEMDA HSU, 2003), h. 73. Penulis tidak menemukan koran NRC yang disebutkan oleh Yusni Antemas itu hingga tulisan ini disusun.

${ }^{49}$ Indonesia Merdeka, 8 Februari 1953.

${ }^{50}$ Merdeka, 6 Februari 1953.

${ }^{51}$ Lihat Sajuti Melik, Negara Nasional ataukah..., h. 8.

52Abdurrahman, "Beberapa Catatan Seputar Pidato Politik Amuntai yang Menghebohkan”, dalam Banjarmasin Post, edisi Kamis, 14 Juni 2001. 


\section{Jawaban Soekarno}

Pidato yang disampaikan oleh Soekarno dalam kuliah umum di hadapan civitas akademika Universitas Indonesia Jakarta tanggal 7 Mei 1953 yang berjudul "Negara Nasional dan Tjita2 Islam", adalah yang penulis anggap sebagai tanggapan resmi Sang Presiden terhadap polemik seputar "Peristiwa Amuntai 1953". ${ }^{33}$ Pertama-tama reaksi atas pidatonya di Amuntai dengan menyebutnya sebagai "gara-gara Amuntai", hal ihwal ini dikatakannya secara tegas sebagai berikut:

Sudah barang tentu satu orang jang duduk disini atau berdiri disini jang tidak mengetahui akan "gara2 Amuntai". Bukan saja maksudkan dengan perkataan "gara2" itu ribut2-an, sama sekali tidak. Tetapi terbangunnja minat mengenai soal jang didalam tjeramah ini hendak saja kupas, jaitu soal mengenai negara nasional dan Tjita2 Islam. Sebenarnja telah lama diminta kepada ku untuk memberi penjdelasan sekadarnja tentang pidato saja di Amuntai itu dan pendjelasan itupun buat sebagian telah saja berikan tatkala saja berdiri dihadapan chalayak ramai di Kotaradja beberapa bulan jang lalu, dihadapan puluhan ribu rakjat jang buat sebagian jang terbesar berdiri dari orang2 jang beragama Islam. ${ }^{54}$

Soekarno dalam pidatonya ini, menyebutkan ihwal "Pidato Amuntai 1953" dalam dua hal. Meskipun pada dasarnya hanya menyangkut satu pokok persoalan saja, yaitu bagaimana keberadaan cita-cita Islam dalam satu negara nasional. Pertama disebutnya:

Dan saudara2, tatkala aku berdiri di Amuntai menghadapi pertanjaan Bung Karno, minta pendjelasan: Negara Nasionalkah atau Negara Islamkah? Pada wakktu itu aku berdiri disana sebagai Presiden Republik Indonesia, tidak sekedjap matapun aku mempunjai lubuk pikiran dibelakang kepalaku ini melarang kepada pihak, Islam untuk mengandjurkan atau mempropagandakan tjita2 Islam. Sama sekali tidak. Kita mempunjai

${ }^{53}$ Robert E. Elson, The Idea of Indonesia (Cambridge: Cambridge University Press, 2008), h. 247; Lihat juga Boyd R. Compton, h. XLV.

${ }^{54}$ Arsip Departemen Penerangan Republik Indonesia: teks kuliah umum oleh Presiden Soekarno di Universitet Indonesia Djakarta pada 7 Mei 1953, berjudul "Negara Nasional dan Tjita2 Islam", h. 1; Lihat juga Nurcholish Madjid, "The issue of modernization among Muslims in Indonesia: from participant's points of view", in Ahmad Ibrahim, Sharon Siddique \& Yasmin Hussain (eds.), Readings on Islam in Southeast Asia (Singapura: ISEAS, 1985), h. 4. 
undang2 dasar jang dengan tegas berdiri diatas dasar Pantjasila, jang salah satu dari padanja ialah dasar demokrasi. ${ }^{55}$

Kedua, dikemukakan pula oleh Bung Karno secara rinci tentang maksud dari "Pidato Amuntai 1953" ini sebagai berikut:

Djadi tatkala aku berdiri di Amuntai, berhadapan dengan chalajak ramai, warga-negara2 Indonesia dan mereka tanjakan kepadaku: Ini Negara demikianlah anggapanku, Negara ini, entah Negara Nasionalkah atau Negara Islamkah? Aku sebagai Presiden jang terikat kepada sumpah: melindungi, mendjaga, mendjungdjung tinggi konstitusi, aku mendjawab, djuga dengan tegas: Negara ini, Negara sekarang ini, adalah Negara Nasional. Sebab tegas pula didalam Preambule (Mukaddimah) dari pada konstitusi itu, baik konstitusi Negara R.I.S. apa pula Negara R.I. jang dulu, tetapi djuga didalam konstitusi, Undang2 Dasar Sementara Negara Kesatuan sekarang ini adalah Negara Nasional, aku tidak mengurangi sedikitpun haknja tiap2 warga negara untuk mempunjai faham sendiri untuk mempropagandakan paham2nja itu sendiri. Orang Islam, kataku di Amuntai, mempunjai hak penuh untuk mempropagandakan tjita2nja, sebagaimanapun organisasi Komunis mempunjai hak penuh untuk mempropagandakan tjita2nja. Itupun adalah satu anasir daripada sumpah saja. Aku diwadjibkan sumpah melindungi konstitusi. Didalam konstitusi itu ternjata terjamin hak2 manusia. Oleh karena itu Saudara2, djanganlah Saudara2 mengira bahwa djikalau aku berkata Negara ini adalah Negara Nasional, aku melarang engkau mempropagandakan Negara Komunis, faham komunis, ideologie komunis, atau engkau mempropagandakan faham Islam, tjita2 bahkan umpama diantara kita ini oleh satu orang jang bertjita2kan national-socialisme, nazidom, fascism, hak penuh untuk mempropagandakan ideologie naziisme. itu. Komunis mempunjai hak, penuh untuk mempropagandakan ideologienja. Saudara2 ini bagian pidato saja jang tadi, untuk memberi pengertian sekedarnja kepada Saudara2 kaum nasionalis tentang tjita2 Islam dan kepada Saudara2 Islam tentang hak, penuhnja untuk mempropagandakan ideologienja. ${ }^{56}$

Demikian antara lain pembelaan Bung Karno atas "Peristiwa Pidato Amuntai 1953"-nya yang terkenal itu. Isinya memang hanya sebuah pembelaan dalam bentuk penjelasan agar ide-ide yang telah dilontarkannya dapat diterima oleh setiap orang Islam.

${ }^{55}$ Arsip Kementerian Penerangan R.I., h. 4-5.

${ }^{56}$ Arsip Kementerian Penerangan R.I., h. 8-9. 


\section{Penutup}

Dinamika pertempuran wacana antara kelompok Nasionalis Netral Agama (dalam hal ini dimotori oleh Soekarno) dengan kelompok Islam dalam "Pidato Politik Soekarno di Amuntai 27 Januari 1953" adalah panggung kontestasi kuasa politik atas rakyat Amuntai, khususnya, dan rakyat Indonesia umumnya. Roda percaturan politik wacana ini, dijalankan oleh Soekarno sebagai bagian dari kelompok Nasionalis Netral Agama yang berhadapan dengan kelompok Islam. Pertarungan diskursus wacana "Negara Islam" yang diduelkan dengan "Negara Nasional" dalam pidato Amuntai-Soekarno tersebut, dikritik secara tegas oleh kelompok Islam sebagai ajang kampanye terselubung dan doktrin yang membahayakan terhadap cita-cita perjuangan berdirinya negara Islam. Perang wacana kemudian meledak di media cetak dengan topik "Pidato Politik Soekarno di Amuntai 27 Januari 1953" sebagai ajang kontestasi berkepanjangan yang mengarah kepada kecurigaan dan ketidakpercayaan satu sama lain antara kedua kelompok elite politik Indonesia ini. Isu "Negara Islam" versus "Negara Nasional” sebagai pengetahuan politik yang hangat pada awal 1950-an hingga pelaksanaan pemilu 1955 merupakan tindakan yang sengaja dibuat, direkonstruksi, dan disebarkan oleh kelompok Islam dan kelompok Nasionalis Netral Agama (yang telah bermetamorfosa menjadi partai politik) untuk mempropagandakan misi-misi politik demi memenangkan pemilu 1955 dan merebut kekuasaan negara. Rakyat Indonesia yang menjadi ajang perebutan bagi kedua kelompok demi mendapat simpati dan dukungan lumbung suara ketika pelaksanaan pemilu.

\section{Daftar Pustaka}

\section{Arsip:}

Arsip Departemen Penerangan Republik Indonesia: teks kuliah umum oleh Presiden Soekarno di Universitet Indonesia Djakarta pada 7 Mei 1953, berjudul "Negara Nasional dan Tjita2 Islam".

Arsip milik PERSIS: riwayat hidup KH. Muhammad Isya Ansyari, Tahun 1953. Arsip pribadi Milik Yusni Antemas, t.td. 


\section{Buku dan Skripsi:}

Achmad Fedyani Saifuddin, Konflik dan Integrasi Perbedaan Fabam dalam Agama Islam. Jakarta: Rajawali (1986).

Ahmad Makkie (ed.), Apa \& Siapa Dari Utara Profil Dan Kinerja Anak Banua, Jakarta: Surya Garini (t.t.).

Ahmad Muhajir, Idham Chalid: Guru Politik Orang NU, Yogyakarta: Pustaka Pesantren (2007).

Alfani Daud, Islam dan Masyarakat Banjar Diskripsi dan Analisa Kebudayaan Banjar, Jakarta: Rajawali (1997).

Alfian, Hasil Pemilihan Umum untuk Dewan Perwakilan Rakyat (DPR), Jakarta: Leknas LIPI (1971).

Alfitra Salam, "Pemilihan Umum dalam Perspektif Sejarah: Pengalaman 1955", Dalam Syamsuddin Haris, dkk., Menggugat Pemilihan Umum Orde Baru, Jakarta: USAID \& Obor (1998).

Anggraini Antemas, 17 Tahun Kabupaten Hulu Sungai Utara 1952-1969 dan Lintasan Sedjarah Perdjuangannja, Amuntai: Pemda HSU, (1969). , Lintas Sejarah Perjuangan Kemerdekaan dan Berdirinya Kabupaten Hulu Sungai Utara, Amuntai: Pemda HSU (2003).

Arief Mudatsir Mandan (ed.), Napak Tilas Idham Chalid.Tanggung Jawab Politik NU dalam Sejarah, Jakarta: Pustaka Indonesia Satu (2008).

Compton, Boyd, Kemelut Demokrasi Liberal: Surat-Surat Rahasia, a.b.: Hamid Basyaib, Jakarta: LP3ES (1992).

Deliar Noer, Partai Islam di Pentas Nasional: Kisah dan Analisa Perkembangan Politik Indonesia 1945-65, Edisi kedua, Bandung: Mizan (2000).

Einar Martahan Sitompul, NU dan Pancasila: Sejarah dan Peranan NU dalam Perjuangan Umat Islam di Indonesia dalam Rangka Penerimaan Pancasila sebagai Satu-satunya Asas, Jakarta: Sinar Harapan (1996).

Eka Dolok Martimbang, Profil H. Syafriansyah, Pikiran dan Prilaku Islami, Jakarta: Mardi Mulyo (2003).

Elson, R.E., The Idea of Indonesia: A History, Cambridge: Cambridge University Press (2008). 
Endang Saifuddin Anshari, Piagam Jakarta 22 Juni 1945 dan Sejarah Konsensus Nasional Antara Nasionalis Islami dan Nasionalis "Sekuler" Tentang Dasar Negara Republik Indonesia 1945-9, Bandung: Pustaka (1983).

Feith, Herbert, The Decline of Constitutional Democracy in Indonesia, Ithaca: Cornell University Press (1962). , Pemilihan Umum 1955 di Indonesia, a.b.: Nugroho Katjasungkana; dkk, Jakarta: KPG (1999).

Legge, David, Sukarno: A Political Biography, Second editions, Sydney: Allen \& Unwin (1984).

Muhammad Iqbal, "Soekarno: Bapak Revolusi Indonesia", dalam Iswara N. Raditya (ed.), 7 Bapak Bangsa, Jakarta: Rahzenbook \& Blora Institute (2008).

-------, "Menyulut Api di Padang Ilalang: Pidato Politik Soekarno di Amuntai 27 Januari 1953" Yogyakarta: Universitas Negeri Yogyakarta, (2009). Skripsi tidak dipublikasikan.

Nurcholish Madjid, "The issue of modernization among Muslims in Indonesia: from participant's points of view", in Ahmad Ibrahim, Sharon Siddique \& Yasmin Hussain (eds.), Readings on Islam in Southeast Asia, Singapura: ISEAS (1985).

Pramoedya Ananta Toer, Tjerita dari Blora, Djakarta: t.p (1952).

Sajuti Melik, Negara Nasional atankah Negara Islam, Jogjakarta: Kedaulatan Rakjat (1953).

Van Dijk, Cees, Darul Islam Sebuah Pemberontakan, Jakarta: Grafiti Press (1993).

\section{Makalah:}

Abdurrahman, "Peristiwa Amuntai 1953 dan Pengaruhnya Terhadap Perkembangan Politik di Indonesia", Banjarmasin: Makalab Diskusi Redaksi Harian Banjarmasin Post pada Sabtu, 19 September 1998.

\section{Media Cetak:}

Abadi, 12 Februari 1953.

Abadi, 2 Maret 1953. 
Abadi, 4 Maret 1953.

Abadi, 5 Maret 1953.

Aliran Islam, No. 46, tahun VII, edisi Maret 1953.

Aneta, 2 Februari 1953.

Antara, 29 Januari 1953.

Banjarmasin Post, edisi Kamis, 14 Juni 2001.

Hikmah, No. 9, tahun VI, edisi 28 Februari 1953.

Indonesia Merdeka, 8 Februari 1953.

Jurnal Republik, edisi Selasa, 8 Januari 2008.

Media Kalimantan, 3 Maret 2011.

Merdeka, 6 Februari 1953.

Mimbar Penerangan, tahun IV, No. 2, edisi Februari 1953.

Pedoman, 23 Februari 1953.

Sin Po, 11 Maret 1953.

Tempo, edisi 36/XXX 05 November 2001. 